\title{
INFLUENCE OF AN INSTRUCTIONAL STRATEGY ON THE ATTITUDES OF UNIVERSITY PROFESSORS TOWARD DISTANCE EDUCATION
}

\author{
Dr. Juan Ignacio Barajas VILLARRUEL \\ ORCID: 0000-0001-6908-8731 \\ Faculty of Accounting and Administration, Autonomous University of San Luis Potosi \\ San Luis Potosi, Mexico \\ Dr. Ricardo Noyola RIVERA \\ ORCID: 0000-0003-1360-2820 \\ Faculty of Accounting and Administration, Autonomous University of San Luis Potosi \\ San Luis Potosi, Mexico \\ Dr. Maria Gregoria Benitez LIMA \\ ORCID: 0000-0003-2233-3693 \\ Faculty of Accounting and Administration, Autonomous University of San Luis Potosi \\ San Luis Potosi, Mexico
}

Received: 13/06/2018 Accepted: 05/09/2018

\begin{abstract}
The purpose of the study was to determine the influence of an instructional strategy for the use of DOKEOS, Course Management System (CMS) on the attitudes of professors toward distance education. The study was carried out in the Faculty of Accounting and Administration of a Mexican Public University. The research design was non-experimental with a group of twenty-five professors who were selected through purposive sampling. A questionnaire, which was an attitude scale toward the use of an administration system of online courses, was administered to participants before and after the implementation of an instructional strategy on the use of DOKEOS. Afterwards, usage statistics was examined between weeks three and six. Data analysis included calculation frequency, median, mode and standard deviation. The significant differences between the median of the pre-tests and post-tests were analysed, and then the t-test was administered. Results showed that the instructional strategy contributed to a more positive attitude of professors toward distance education.
\end{abstract}

Keywords: Vocational training, teacher attitudes, teacher effectiveness, distance education, classroom techniques, educational technology.

\section{INTRODUCTION}

The use of computers is one of the main changes that has taken place in the context of technology for the last 150 years. This technology, according to Lopez and Chavez (2013) have led to changes in the activities of the society as a whole, being education the area with the most notable changes and demands. In this respect, Karsenti \& Lira (2011), pointed out that Information and Communication Technologies (ICT) are part of diverse study programs as an effective means to promote educational success, and that they represent a priority for the teaching and learning processes in several countries in America and Europe.

In the case of Mexican universities, Andion (as cited in Araiza, 2009) pointed out that the integration process of the ICT has been difficult and slow. In addition, there is resistance and little interest of professors 
towards the use of this tool. According to Silva and Astudillo (2012), a major barrier is the attitude that the teacher adopts with respect to ICT, which is related to teachers' beliefs and experiences.

Also, Lopez y Chavez (2013), mentioned that international and national organizations have pointed out that the use of ICT in education is a challenge for teaching and learning traditional approaches. In this respect, UNESCO (2013) highlighted that professors are frequently considered as a major external influence for classroom learning, as well as for education in general. This is mainly because of the essential role teachers play in the implementation of ICT. Also UNESCO (2013) mentioned professors need to know how to teach students to use the ICT effectively.

In this regard, Lopez and Chavez (2013) stated it is essential that departments and educational institutions focus their efforts on the preparation of teachers in accordance with the guidelines of the emerging educational models and training demands of the 21 st century Students. The above, raises the question of the importance of training higher education professors in the effective use of ICTs, which implies dealing with the resistance to change that is often found due to the lack of comprehensive training projects.

In this vein, it can be said that professors' resistance to the incorporation of distance education (EaD) is considered an obstacle for the development of this type of educational programs in Higher education institutions (Tejedor et al., 2009). In order to offer an online study program (EaD) in the Faculty of Accounting and Administration (FCA) of a Mexican public university, it is central to consider the participation of professors. Based on the current curricular model, professors at the FCA conduct their lectures in a presencebased modality (Facultad de Contaduria y Administracion, 2016) and they do not have experience in the delivery and design of online educational contents.

On the other hand, the Course Management System (CMS) DOKEOS was introduced in 2007, with the aim of having technological means to assist the institution's educational processes. In addition, investments were made in technological infrastructure, and the permanent training program for users of technological resources of the FCA was created. However, the resistance problem toward the use of CMS DOKEOS at the FCA still remains. (Barajas, 2015a).

The professors' opposition against the use of CMS DOKEOS was determined on the bases of the following factors: (a) the usage statistics retrieved from CMS DOKEOS and (b) the results from the Diagnosis of the Services offered through Information Technologies at the Faculty of Accounting and Administration (Barajas, 2015a). The first factor was obtained from the usage statistics of CMS DOKEOS for the tools administration module, which shows the frequency of access to CMS DOKEOS, used tools, connection time, and the highest affluence hours into the system. Specifically, and based on the cohort of August/ December 2015, results show that 23\% of 268 professors used one of the CMS DOKEOS tools for their courses (Barajas, 2015b).

The second factor was retrieved from the results of the Diagnosis of the Services offered through Information Technologies at the Faculty of Accounting and Administration (Barajas, 2015a), which is based on the international model Control Objectives for Information and Related Technology (COBIT). The results of this diagnosis showed the main obstacles to the adoption of $\mathrm{EaD}$ as follows: (a) the limited use of technological infrastructure of the FCA; (b) the lack of skills for the use of multimedia rooms, laboratory practices; and (c) the lack of effective training in the use of CMS DOKEOS. On this matter, $66 \%$ of the professors pointed out the absence of training in the use of CMS DOKEOS (Barajas, 2015b).

On this basis, the research problem in this study is the absence of an effective training strategy to promote positive attitude of professors toward distance education. This research problem is focused on higher education institutions in Mexico and their tendency to promote distance education with the support of academic staff effectively trained for this type of instruction (Amador, 2010).

\section{THEORETICAL FRAMEWORK}

\section{Instructional Design}

Some elements need to be considered in a training process, as well as the components and links between them. This way the nature of such process can be determined. According to Sangra (2000), it is essential to analyse 
the content of the course, the procedure that will facilitate learning, and also the necessary technological resources for the training progress.

In this respect, the concept of instructional design is presented as a process that specifies clearly all the elements that are part of the training and the link between them (Guardia, 2000). In addition, Gonzalez (2017), pointed out that the concept of instructional design is oriented towards the creation of learning environments that facilitate educational processes through the use of technological tools. According to this author, this concept links two dimensions: the technological and the pedagogical.

Based on the above, the definition of instructional design in this research is based on the one presented by Williams, Schrum, Sangra and Guardia (s/f), who pointed out that the instructional design describes a process divided into the following stages: (a) needs analysis of learning and the context where such needs occur, (b) definition of learning objectives (c) resources selection and/or appropriate technological means for the learning process, (d) development of contents and learning activities, and (e) assessment design.

\section{Attitudes of Professors Toward the Use of Information and Communication Technologies (ICT)}

According to Robbins and Judge (2009), attitudes are part of the human behaviour and they are learned from the different social groups in which the individual is involved. In this process, people adopt certain predispositions from other persons they admire, love or are afraid of. On the other hand, attitudes can be shaped based on the individual or group interest. Another important aspect of the attitudes is their influence on behaviour; hence, some look for congruence between attitudes and behaviour (Robbins and Judge, 2009).

For the purpose of this research, after the analysis of different concepts of attitude, the most pertinent definition was the one described by Eagly and Chaiken, as cited in Lopez (2004), who pointed out that an attitude is a psychological standpoint that occurs through the evaluation of a particular entity, with a determined approved or non-approved gradation.

In terms of professors' attitudes and their use of ICT, according to Rodriguez (2012), one of the major concerns of professors is that the training they receive is effective. In this respect, Almekhlafi and Almekhlafy (2010) carried out a studio about the attitude of professors toward the usefulness of on-line instruction; results revealed positive opinions and attitudes toward the usefulness of on-line instruction.

On the other hand, Banuelos, as cited in Lignan-Camarena (1999), found that most professors have moderate intentions to use ICT, and that attitude is the most important determinant in the behaviour intention and not the subjective norm. This shows that the intention of using ICT is based on self-control and not on social pressure.

Based on the foregoing, the objective of this study was to evaluate if the professors' attitudes have improved due to their training in ICT as pointed out by Gilmore, as cited in Orellana, Almerich, Belloch, and Diaz (2004). In this case the aim is to determine the professors' predisposition after participating in an instructional strategy for the use of CMS DOKEOS as a mean to offer EaD.

\section{Course Management System (CMS)}

The course management systems (CMS) are a type of technological platform. The technological platforms are a "wide range of software applications installed in a server whose role is to facilitate the creation, administration, management and distribution of courses via the internet" or to be a course repository (Sanchez, 2005. p. 19). According to Avila and Bosco (2001), the use of technological platforms proves to be very attractive in terms of training.

Within this framework, the main features of a technological platform are: (a) it allows to create virtual working spaces, (b) it does not require to be present in a classroom, (c) the teacher's attendance is not necessary, (d) there is no need to establish specific timetables, and (e) it can be adapted to different needs, such as the availability of time (Avila y Bosco, 2001). These characteristics help users perform their activities without depending on others; also, they encourage users to look for additional information on their own (De Benito, 2000). In this vein, according to Graft and Albright (2007), a Course Management System (CMS) is defined as a type of technological platform that is part of a learning management system or an independent 
system. These authors defined a CMS as a program that allows the development of a support structure to create and administrate courses, mainly web pages.

On the other hand, according to Garcia and Castillo, (as cited in Sanchez, 2005), a CMS is a platform that has evolved rapidly in the training activities market over the internet. The CMS can be found in this group of platforms, which are distributed under the General Public License (GPL). This type of platforms offers the user some choices, apart from being free (Stallman, 2005). The CMS DOKEOS are found in this type of platforms.

CMS DOKEOS is a web application that contains a wide variety of tools for training and education. The course management in this CMS is done through three groups of tools: (a) tools for the contents development, which includes the creation of course, exercises, documents and links; (b) tools of interaction, consisting of the course timetable, forums, users, ads and tasks, and (c) the administration tools which include the course settings, maintenance and reports which allow the recovery of statistical information about the use of the course tools and the participation of those registered (Marquez, 2005).

\section{Distance Education (EaD)}

Distance education $(\mathrm{EaD})$ is among the main trends in education modality, the objective is to assist the social demands in terms of training, quality and relevance are central in this type of education. Keegan, (as cited in Edel, Garcia and Tiburcio, 2008), defined the $\mathrm{EaD}$ as a teaching-learning scenario where the professor and the students are separated, they support each other with printed and electronic materials, and their main goal is to learn.

The EaD should not be defined as contrasting to the face-to face or classroom-based education (Orozco, 2000). According to this author, it is necessary to conceptualize the EaD based on the use of media and ICT, which are the innovative references in the education process and also their support.

The organization: Espacio Comun de Educacion Superior a Distancia de Mexico, defines EaD as follows, cited in Lupion and Rama (2010):

An effort to strengthen the educational systems recovering spaces as well as educational processes globally and permanently, this way access to educational services different from the traditional classroom-based courses is open to those interested in them. This is then the purpose of the development of strategies to connect people who take part in educational processes, even if they do not coincide in place and time (p. 149).

Having analysed concepts of $\mathrm{EaD}$, this type of education can be considered as formal schooling than can be distance in space and time, in part or permanently; and it is based, to a greater or lesser degree, on the management of learning experiences through ICT.

\section{PURPOSE OF THE STUDY}

To determine the influence of an instructional strategy for the use of CMS DOKEOS on the attitudes of professors toward distance education in the Faculty of Accounting and Administration of a Mexican Public University.

\section{Research Questions}

1. What is the attitude of professors toward $\mathrm{EaD}$ before their participation in an instructional strategy on the use of CMS DOKEOS, in the Faculty of Accounting and Administration of a Mexican Public University?

2. What is the influence of an instructional strategy on the use of CMS DOKEOS on the attitudes of the professors toward $\mathrm{EaD}$, in the Faculty of Accounting and Administration of a Mexican Public University?

3. What is the percentage of use of the CMS DOKEOS tools by professors, after three and six weeks of participating in the instructional strategy on the use of this system, in the Faculty of Accounting and Administration of a Mexican Public University? 


\section{METHOD}

The research design was non-experimental with a group of twenty-five professors who were selected through purposive sampling. The data to answer questions one and two were collected through a questionnaire named Attitude Scale toward the Use of a Course Management System on Line.

For question number three, descriptive statistics was examined and compared between weeks three and six, after the post-test on the use of CMS DOKEOS. Such statistics refers to the percentage of use of the system tools by 25 professors who participated in the study, thus showing the most and least used tools.

\section{Participants}

The characteristics of the professors who participated in this study are described as follows: (a) they were teaching at least one of the study programs of the BA degrees at the FCA, and (b) they had not used the CMS DOKEOS before the training proposed for this study. A purposive non-probabilistic sample was applied. The sample consisted of 25 participants out of a population of 127 professors, who met the requirements mentioned above. It is important to point out that the selection of professors for the sample of this study was anonymous. It is also relevant to mention that the reason of the 25 sample was because it was the highest number of professors who decided to take part in the course, besides they were available during the offered timetable.

\section{Data Collection and Analysis}

A questionnaire named Attitude Scale toward the Use of a Course Management System on Line was designed for the data collection. Such instrument was created based on the questionnaire administered in the study conducted by Lopez (2004). The instrument was structured as follows: objective, instructions and 30 closedended questions. The section of the closed-ended questions considers the following dimensions: (a) emotional level in the use of a management course system online $(5,7,10,12,13,14,15,16,18,19,22,24,27,28 \mathrm{y}$ 29); (b) benefits of the use of a management course system online (1, 2, 3, 4, 6, 9, 20, 23, 25 y 26); and (c) self-learning in the use of a management course system online $(8,11,17,21$ y 30). The answer choices of the questionnaire were: 1 (totally agree), 2 (agree), 3 (indecisive), 4 (disagree) y 5 (totally disagree). After the questionnaire design, two types of validation were carried out: (a) one based on content, and (b) a pilot test.

According to Nadelsticher (1983), content validity of the measurement instrument statements can be determined by competent judges and experts. In order to ensure the content validity of the questionnaire: Attitude Scale toward the Use of a Course Management System on Line, the 30 closed-ended questions were revised by two methodology and statistics experts, the aim was to know their opinion in terms of the content of these items. It is important to point out these experts have taken part in Distance education models supported by the use of CMS. They suggested to make some changes in the questionnaire items: four, seven, and thirteen. There was no need to remove questions.

For the second validation, a pilot test was administered to 15 professors who met the selection criteria but were not part of the defined sample for this study. Then, in order to validate the congruency of the 30 items of the instrument, the Alfa de Cronbach was applied. The general results of the validation were 0.779 , which according to George and Mallery (2003), an alfa coefficient value higher to 0.7 is acceptable.

The data obtained from the questionnaire were processed through descriptive statistics. A matrix organization was used for the statistical processing of the questions. Frequencies, measures, and central tendency were calculated: mean, mode and the measure of variability: standard deviation, for each one of the 30 items. The Statistical Package for the Social Sciences (SPSS ${ }^{\circ}$ ), version 20.0. was used to process the information. Table 1 and 2 show the results of this analysis.

Also, an analysis of significant differences between the pre-test and post-test means of the three questionnaire dimensions was carried out; then the $t$ test was administered. Pre-test and post-tests results were compared at two different times (Tables 3, 4 and 5). The degrees of freedom calculated for this study are $g l=48$; which were obtained from the total of participants in both, the pre-test and the post-test minus 2 . These degrees of freedom represent the number of ways in which the data can vary freely. 


\section{FINDINGS}

The information from the pre-test administered to the 25 professors was analysed descriptively. The results are showed in the table 1:

Table 1. Dispersion and central tendency measures of the pre-test questionnaire

\begin{tabular}{|c|c|c|c|c|}
\hline No. & Items & Mean & Mode & $\begin{array}{l}\text { Standard } \\
\text { Deviation }\end{array}$ \\
\hline 1 & Using a CMS favours my perspective of distance education. & 3.040 & 3 & 0.888 \\
\hline 2 & $\begin{array}{l}\text { The use of a CMS encourages me to perform a more interesting and imaginative work } \\
\text { while I am teaching the course. }\end{array}$ & 2.720 & 3 & 1.137 \\
\hline 3 & A CMS encourages me to use my personal abilities. & 3.200 & 3 & 1.154 \\
\hline 4 & A CMS makes higher education in Mexico progress. & 2.680 & 3 & 1.107 \\
\hline 5 & $\begin{array}{l}\text { If I had the chance to use a CMS, I would be afraid to damage the equipment } \\
\text { somehow. }\end{array}$ & 2.360 & 1 & 1.439 \\
\hline 6 & $\begin{array}{l}\text { The use of a CMS allows me to do a more interesting and imaginative work while } \\
\text { teaching a course. }\end{array}$ & 2.880 & 3 & 0.927 \\
\hline 7 & $\begin{array}{l}\text { The use of a CMS prevents me from doing a more interesting and imaginative work } \\
\text { while teaching a course. }\end{array}$ & 2.440 & 2 & 1.083 \\
\hline 8 & It is important to have an instruction manual to learn how to use a CMS. & 3.560 & 3 & 1.157 \\
\hline 9 & A CMS is a major contribution to higher education in Mexico. & 2.880 & 3 & 1.129 \\
\hline 10 & Using a CMS makes me feel uncomfortable. & 2.360 & 2 & 1.150 \\
\hline 11 & I need someone to tell me what the best way to use a CMS is during the course. & 2.960 & 4 & 1.337 \\
\hline 12 & The use of a CMS limits the teaching practice. & 2.520 & 3 & 1.045 \\
\hline 13 & Using a CMS is irrelevant in my teaching practice. & 2.480 & 2 & 1.228 \\
\hline 14 & The use of CMS is a passing trend & 2.320 & 2 & 1.215 \\
\hline 15 & I think using a CMS is a waste of time. & 2.080 & 1 & 1.187 \\
\hline 16 & It is difficult for me to learn how to use a CMS properly. & 2.440 & 3 & 1.003 \\
\hline 17 & In one way or another, I can solve the problems I have when I use a CMS. & 2.520 & 3 & 0.918 \\
\hline 18 & In order to look less inexpert (a) I would prefer to stop using a CMS. & 2.200 & 2 & 0.912 \\
\hline 19 & I am bored by the idea of using a CMS in my teaching practice. & 2.120 & 1 & 1.166 \\
\hline 20 & I could spend a lot of time using a CMS. & 3.040 & 3 & 1.019 \\
\hline 21 & $\begin{array}{l}\text { Every time I take a course in the use of a CMS it is necessary for me to be close to a } \\
\text { person with more experience in using the tool. }\end{array}$ & 3.160 & 4 & 1.178 \\
\hline 22 & Using a CMS inhibits my teaching practice. & 2.720 & 3 & 1.275 \\
\hline 23 & Using a CMS favors the educational process. & 3.120 & 4 & 1.363 \\
\hline 24 & The use of CMS impedes the way of learning & 2.120 & 2 & 0.781 \\
\hline 25 & The use of a CMS encourages me to keep going. & 2.760 & 3 & 0.879 \\
\hline 26 & The CMS cause changes in the higher education system in Mexico. & 3.200 & 3 & 1.118 \\
\hline 27 & Using CMS makes me feel insecure in what I am doing. & 2.360 & 2 & 1.220 \\
\hline 28 & Working with a CMS makes me nervous. & 2.440 & 3 & 1.121 \\
\hline 29 & Learning to use a CMS seems complicated to me. & 2.160 & 2 & 0.9865 \\
\hline 30 & I could use a CMS independently without asking help from others. & 2.840 & 3 & 1.106 \\
\hline
\end{tabular}

Source: Own elaboration

In addition, the information from the post-test administered to the 25 professors was analysed descriptively. Results are shown in the table 2. 
Table 2. Central and tendency measures and dispersion of the post-test questionnaire

\begin{tabular}{|c|c|c|c|c|}
\hline No. & Items & Mean & Mode & $\begin{array}{l}\text { Standard } \\
\text { Deviation }\end{array}$ \\
\hline 1 & Using a CMS favors my perspective of distance education. & 4.240 & 4 & 0.723 \\
\hline 2 & $\begin{array}{l}\text { The use of a CMS encourages me to perform a more interesting and imaginative } \\
\text { work while I am teaching the course. }\end{array}$ & 4.200 & 4 & 0.816 \\
\hline 3 & A CMS encourages me to use my personal abilities. & 4.480 & 5 & 0.585 \\
\hline 4 & A CMS makes higher education in Mexico progress. & 4.240 & 5 & 0.969 \\
\hline 5 & $\begin{array}{l}\text { If I had the chance to use a CMS, I would be afraid to damage the equipment } \\
\text { somehow. }\end{array}$ & 2.840 & 1 & 1.518 \\
\hline 6 & $\begin{array}{l}\text { The use of a CMS allows me to do a more interesting and imaginative work while } \\
\text { teaching a course. }\end{array}$ & 4.320 & 4 & 0.627 \\
\hline 7 & $\begin{array}{l}\text { The use of a CMS prevents me from doing a more interesting and imaginative work } \\
\text { while teaching a course. }\end{array}$ & 3.120 & 4 & 1.332 \\
\hline 8 & It is important to have an instruction manual to learn how to use a CMS. & 3.960 & 4 & 1.098 \\
\hline 9 & A CMS is a major contribution to higher education in Mexico. & 4.240 & 5 & 0.830 \\
\hline 10 & Using a CMS makes me feel uncomfortable. & 2.600 & 2 & 1.443 \\
\hline 11 & I need someone to tell me what the best way to use a CMS is during the course. & 3.680 & 4 & 1.144 \\
\hline 12 & The use of a CMS limits the teaching practice. & 2.480 & 2 & 1.228 \\
\hline 13 & Using a CMS is irrelevant in my teaching practice. & 2.160 & 2 & 0.986 \\
\hline 14 & The use of CMS is a passing trend & 2.560 & 2 & 1.356 \\
\hline 15 & I think using a CMS is a waste of time. & 2.200 & 1 & 1.118 \\
\hline 16 & It is difficult for me to learn how to use a CMS properly. & 2.680 & 2 & 1.107 \\
\hline 17 & In one way or another, I can solve the problems I have when I use a CMS. & 4.240 & 4 & 0.925 \\
\hline 18 & In order to look less inexpert (a) I would prefer to stop using a CMS. & 2.360 & 2 & 1.075 \\
\hline 19 & I am bored by the idea of using a CMS in my teaching practice. & 2.400 & 1 & 1.224 \\
\hline 20 & I could spend a lot of time using a CMS. & 4.120 & 4 & 0.781 \\
\hline 21 & $\begin{array}{l}\text { Every time I take a course in the use of a CMS it is necessary for me to be close to a } \\
\text { person with more experience in using the tool. }\end{array}$ & 2.960 & 2 & 1.206 \\
\hline 22 & Using a CMS inhibits my teaching practice. & 2.400 & 2 & 0.912 \\
\hline 23 & Using a CMS favours communication in the educational process. & 4.520 & 5 & 0.585 \\
\hline 24 & The use of CMS impedes the way of learning & 2.520 & 2 & 1.262 \\
\hline 25 & The use of a CMS encourages me to keep going. & 4.120 & 4 & 0.881 \\
\hline 26 & The CMS cause changes in the higher education system in Mexico. & 4.480 & 5 & 0.585 \\
\hline 27 & Using CMS makes me feel insecure in what I am doing. & 2.560 & 3 & 1.193 \\
\hline 28 & Working with a CMS makes me nervous (a) & 2.800 & 2 & 1.118 \\
\hline 29 & Learning to use a CMS seems complicated to me. & 2.360 & 2 & 1.150 \\
\hline 30 & I could use a CMS independently without asking help from others. & 4.040 & 5 & 1.135 \\
\hline
\end{tabular}

Source: Own elaboration

\section{Difference between Pre-test and Post-test Means}

Tables 3, 4 and 5 show the analysis results of the significant differences between the means of the pre-test and post-test of the questionnaire dimensions: (a) Emotion showed in relation to the use of a course management system online, (b) benefits of using a course management system online, and (c) Self-learning regarding the use of a course management system online.

Also, the table below shows the $t$ test results for each dimension of the questionnaire. The results of this test allowed the comparison of significant differences between the three dimensions of the pre-test and post- test questionnaires. 
Table 3. Mean difference of the emotion dimension regarding the use of CMS between the pre-test and post- test questionnaires.

\begin{tabular}{|c|c|c|c|c|}
\hline No. & Items & $\begin{array}{l}\text { Pre-test } \\
\text { Mean }\end{array}$ & $\begin{array}{l}\text { Post-test } \\
\text { Mean }\end{array}$ & $\begin{array}{c}\text { Difference } \\
\text { between } \\
\text { Means }\end{array}$ \\
\hline 5 & $\begin{array}{l}\text { If I had the chance to use a CMS, I would be afraid to damage the equipment } \\
\text { somehow. }\end{array}$ & 2.360 & 2.840 & 0.480 \\
\hline 7 & $\begin{array}{l}\text { The use of a CMS prevents me from doing a more interesting and imaginative } \\
\text { work while teaching a course. }\end{array}$ & 2.440 & 3.120 & 0.680 \\
\hline 10 & Using a CMS makes me feel uncomfortable. & 2.360 & 2.600 & 0.240 \\
\hline 12 & The use of a CMS limits the teaching practice. & 2.520 & 2.480 & -0.040 \\
\hline 13 & Using a CMS is irrelevant in my teaching practice. & 2.480 & 2.160 & -0.320 \\
\hline 14 & The use of CMS is a passing trend. & 2.320 & 2.560 & 0.240 \\
\hline 15 & I think using a CMS is a waste of time. & 2.080 & 2.200 & 0.120 \\
\hline 16 & It is difficult for me to learn how to use a CMS properly. & 2.440 & 2.680 & 0.240 \\
\hline 18 & In order to look less inexpert (a) I would prefer to stop using a CMS. & 2.200 & 2.360 & 0.160 \\
\hline 19 & I am bored by the idea of using a CMS in my teaching practice. & 2.120 & 2.400 & 0.280 \\
\hline 22 & Using a CMS inhibits my teaching practice. & 2.720 & 2.400 & -0.320 \\
\hline 24 & The use of CMS impedes the way of learning & 2.120 & 2.520 & 0.400 \\
\hline 27 & Using CMS makes me feel insecure in what I am doing. & 2.360 & 2.560 & 0.200 \\
\hline 28 & Working with a CMS makes me nervous (a) & 2.440 & 2.800 & 0.360 \\
\hline 29 & Learning to use a CMS seems complicated to me. & 2.160 & 2.360 & 0.200 \\
\hline
\end{tabular}

Source: own elaboration.

Table 3 shows there is a difference between the pre-test and post- test means. As it can be observed, in most cases the post-test means were higher than the pre-test means. The 0.195 average and the standard deviation of 0.266 were obtained from the result of the differences between the pre-test and post- test means.

The emotion dimension Means and the pre-test and post- test questionnaires were used to carry out a statistical calculation of the student's paired t- test. The statistical calculation's result was $t=2.83$. In addition, the $t$ value in the Student's $t$ - distribution table was found.

To do so, 14 degrees of freedom were used (total of items -1 ), also a trust level of 0.05 , the value found was $t=1.7613$. The $t$ values (calculated and found values in the $t$-student's table) are different, and for his reason it can be said that there is a difference in the use of a CMS for online courses between the pre-test and posttest in terms of the emotional level.

Table 4. Means difference regarding the benefit dimension in the use of CMS between the pre-test and post-test

\begin{tabular}{|c|c|c|c|c|}
\hline No. & Items & $\begin{array}{c}\text { Pres-test } \\
\text { Mean }\end{array}$ & $\begin{array}{c}\text { Post-test } \\
\text { Mean }\end{array}$ & $\begin{array}{c}\text { Difference } \\
\text { between } \\
\text { Means }\end{array}$ \\
\hline 1 & The use of a CMS favours my perspective of distance education. & 3.040 & 4.240 & 1.200 \\
\hline 2 & $\begin{array}{l}\text { The use of a CMS encourages me to perform a more interesting and } \\
\text { imaginative work at the moment I teach the course. }\end{array}$ & 2.720 & 4.200 & 1.480 \\
\hline 3 & A CMS encourages me to use my personal abilities. & 3.200 & 4.480 & 1.280 \\
\hline 4 & A CMS makes higher education in Mexico progress. & 2.680 & 4.240 & 1.560 \\
\hline 6 & $\begin{array}{l}\text { The use of a CMS allows me to do a more interesting and imaginative work } \\
\text { while teaching a course. }\end{array}$ & 2.880 & 4.320 & 1.440 \\
\hline 9 & A CMS is a major contribution to higher education in Mexico. & 2.880 & 4.240 & 1.360 \\
\hline 20 & I could spend a lot of time using a CMS. & 3.040 & 4.120 & 1.080 \\
\hline 23 & Using a CMS favours communication in the educational process. & 3.120 & 4.520 & 1.400 \\
\hline 25 & The use of a CMS encourages me to keep going. & 2.760 & 4.120 & 1.360 \\
\hline 26 & The CMS cause changes in the higher education system in Mexico. & 3.200 & 4.480 & 1.280 \\
\hline
\end{tabular}

Source: own elaboration 
Table 4 shows there is a difference between the pre-test and post-test means; as it can be observed the posttest means were higher than the pre-test means in all the items. The result obtained from this difference was 1.34 and the standard deviation was 0.140 .

The benefit dimension Means and the pre-test and post- test questionnaires were used to carry out a statistical calculation of the student's paired $t$ - test. The statistical calculation's result was $t=30.33$ Also, the $t$ value in the Student's $t$ - distribution table was found.

To do so, nine degrees of freedom were used (total of items -1 ), also a trust level of 0.05 , the value found was $t=1.8331$. The $t$ values (calculated and found values in the $t$-student's table) differ significantly, so it can be said that there is a difference in the use of a CMS for online courses regarding the benefit dimension.

Table 5. Means difference regarding the self-learning dimension in the use of CMS between the pre-test and post-test

\begin{tabular}{|c|c|c|c|c|}
\hline No. & Items & $\begin{array}{c}\text { Pre-test } \\
\text { Mean }\end{array}$ & $\begin{array}{l}\text { Post-test } \\
\text { Mean }\end{array}$ & $\begin{array}{c}\text { Difference } \\
\text { between } \\
\text { Means }\end{array}$ \\
\hline 8 & It is important to have an instruction manual to learn how to use a CMS. & 3.560 & 3.960 & 0.400 \\
\hline 11 & $\begin{array}{l}\text { I need someone to tell me what the best way to use a CMS is during the } \\
\text { course. }\end{array}$ & 2.960 & 3.680 & 0.720 \\
\hline 17 & $\begin{array}{l}\text { In one way or another, I can solve the problems I have when I using a } \\
\text { CMS. }\end{array}$ & 2.520 & 4.240 & 1.720 \\
\hline 21 & $\begin{array}{l}\text { Every time I take a course in the use of a CMS it is necessary for me to be } \\
\text { close to a person with more experience in using the tool. }\end{array}$ & 3.160 & 2.960 & -0.200 \\
\hline 30 & I could use a CMS independently without asking for help from others. & 2.840 & 4.040 & 1.200 \\
\hline
\end{tabular}

Source: Own elaboration

Table 5 shows the difference between the pre-test and post-test Means of the self-learning dimension of CMS for an online course. The post-test Means were higher than the pre-test means except for item 21 . The result obtained from the difference between the pre-test and post-test Means was an average of 0.768 and the standard deviation was 0.736 .

The self-learning dimension Means and the pre-test and post- test questionnaires were used to carry out a statistical calculation of the student's paired t- test. The statistical calculation's result was $t=2.33$. In addition, the $t$ value in the Student's $t$ - distribution table was found.

To do so, four degrees of freedom were used (total of items -1 ), also a trust level of 0.05 , the value found was $t=2.1318$. The $t$ values (calculated and found values in the $t$-student's table) are different, and for his reason it can be said that there is a difference in the self-learning dimension regarding the use of a CMS for online courses.

After three and six weeks of the professors' participation in the instructional strategy on the use of CMS DOKEOS, the percentage of use of these tools' system was recovered. The data were obtained through the tool denominated reports (Informes) administration tools' which is part of the CMS DOKEOS administration's tool group.

The descriptive statistics refers to the percentage of use of the CMS DOKEOS tools, which identifies the most utilized tools as well as those least used.

Table 6 shows the descriptive statistics of use of the CMS DOKEOS by the 25 professors after three and six weeks of the post-test. 
Table 6. Comparative percentage of the de use of the CMS DOKEOS tools between three and six weeks after the post-test administration

\begin{tabular}{lccc}
\hline \multicolumn{1}{c}{ CMS DOKEOS tools } & $\begin{array}{c}\text { \% of use after three weeks of } \\
\text { the post-test }\end{array}$ & $\begin{array}{c}\text { \% of use after six weeks of the } \\
\text { post-test }\end{array}$ & $\begin{array}{c}\text { Difference between } \\
\text { percentages }\end{array}$ \\
\hline Course Description & 92 & 92 & 0 \\
Exercises & 12 & 72 & 60 \\
Documents & 92 & 100 & 8 \\
Links & 76 & 84 & 8 \\
Agenda & 16 & 12 & -4 \\
Forums & 8 & 20 & 12 \\
Users & 92 & 100 & 8 \\
Notifications & 52 & 80 & 28 \\
Tasks & 68 & 100 & 32 \\
\hline
\end{tabular}

Source: Own elaboration

\section{DISCUSSIONS AND CONCLUSION}

Discussion of the outcomes of this study will be presented based on the research questions as follows.

Research Questions One and Two. The following aspects were considered in the dimension denominated emotion in the use of a CMS: fear, interest, imagination, discomfort, limitations, irrelevance, inexperience, boredom, insecurity, nervousness and difficulty (see table 3). Considering the information from this dimension, it can be said that in most cases the post-test Means were higher than the pre-test Means. The result of the differences between the pre-test and post-test Means was an average of 0.195 and a standard deviation of 0.266 . This means that the teachers who participated in this study, showed a positive attitude toward the emotion dimension regarding the use of the Course Management System. However, it is important to mention that out of the total items in this dimension, only items 12, 13, and 22 showed a negative difference between the pre-test and post-test Means.

Therefore, it can be said that the items linked to the limitation, irrelevance and inhibition aspects in the use of a CMS, were rated with major scales in the pre-test and lower scales in the post-test. Consequently, the result of the difference of these means allows us to interpret that the limitation, irrelevance and inhibition aspects in the use of CMS decreased after the participant took the training.

In this regard, Lopez (2004) stated that the attitude of the professors toward the use of a Virtual Learning Platform, particularly after they were provided with the training, helped decrease their levels of frustration and anxiety. Moreover, they did not show evidence of negative feelings.

In addition, Tejedor and Garcia-Valcarcel (2006) pointed out that the professors' fear of ICT reduces gradually after they have taken the training in the use of these technological tools. They also added that trained professors reported positive appraisals and feelings toward the use of technological means.

In relation to the dimension denominated Benefits of the use of CMS, some aspects regarding the individuals were considered, such as: encouragement, abilities and interest in terms of the use and time spent in the CMS; some other aspects related to higher education in Mexico were considered too, as well as the benefits of this education level in the use of a CMS (see table 4).

Based on the above, it was determined that the post-test means were higher than the pre-test means for all the items. The result of the differences between the pre-test and post-test means was an average of 1.34 and a standard deviation of 0.140 .

In this sense, it can be said that the professors taking part in this study showed a positive attitude toward the dimension: Benefits of the use of the CMS. Consequently, it can be inferred that the participants' opinion on the $\mathrm{EaD}$ improved as a result of the training; and that the professors are more motivated and confident regarding their abilities to use the CMS as a tool that favours communication in their educational processes.

Additionally, the results of the pre-test and post-test means showed that after the training, the participants valued the importance of using the CMS in the higher education level in Mexico. 
In this respect, Barajas, Noyola and Benitez (2012) pointed out the relevance of the use of a course management system as a mean of communication for the educational processes in a higher education institution in Mexico. In addition, these authors stated that the use of a CMS is perceived positively by professors due to the services offered to facilitate the teaching and learning activities, as well as the training processes that favour higher education in Mexico.

On the other hand, Chavez (2010) carried out a study on the effectiveness of a training course on ICT, which showed that motivation for the use of an administrative software increases after participating in a training session supported by the use of a CMS. This study also showed the effectiveness of the training course since professors were able to develop better personal abilities to use and implement the studied software.

The dimension denominated self-learning in the use of a CMS included the professor's opinion about the support they can get from people and materials for the use of the CMS (see Table 5).

Therefore, it can be said that for most of the items of this dimension, the post-test means were higher than the pre-test means. However, it is important to mention that out of the total items in this dimension, only item 21, which is the one related to assistance from an expert in the use of the CMS, showed a negative difference between the pre-test and post-test means.

In this respect, it can be said that the professors participating in the study showed a positive attitude toward the dimension: Self-learning in the use of the CMS. Also, it can be inferred that, as a result of the training, the participants were willing to invest more time in the use of the CMS, to ask for help from experts if necessary, to revise instruction manuals and /or solve possible problems in the use of the CMS.

Regarding the interpretation mentioned above, Vidal-Martinez and Camarena-Gomez (2018), as well as Scagnoli (2005) determined that virtual environments facilitate and promote self-learning because the users of these systems are the ones in charge of the information. However, one of challenges of the use of the CMS is to lead self-learning toward collective knowledge of the CMS's users (Scagnoli, 2005).

Similarly, Lopez (2004) claimed that the initial perception professors had about their ability to use the ICT independently, was transformed after the training they received.

Finally, based on the analysis and interpretation of results, it was concluded that the attitude of the professors toward offering $\mathrm{EaD}$, defined in the dimensions: "Emotion in the use of a CMS", and "Self-learning in the use of a CMS", was affected positively after the professors participated in the "Workshop on instructional design for online courses using CMS DOKEOS".

Research Question Number Three. In order to interpret the difference between the percentage of use of the CMS DOKEOS tools after three and six weeks of the post-test administration, it is necessary to point out that the tools in this comparison are the same ones included in the instructional strategy content of the Workshop on instructional design for online courses using CMS DOKEOS. Based on that information, it can be said that most of the tools of the CMS DOKEOS increased the percentage of use by the participants in this study. However, it is important to mention that the percentage of use remained the same between the three and six weeks of analysis, this was due to the central characteristic of the tool, which implies that the course program is published at the beginning and then there is no need for subsequent adjustments. In the case of the Agenda tool, the percentage decreased 4\%, this might be because professors are accustomed to using a CMS at a presence-base modality, so the usually indicate the activities in person.

As in this study, Chavez (2010), stated that the application level of knowledge after a training course in the use of ICT increased positively. Chavez also reported that the trained professors expressed agreement with the application of their knowledge in their working context. In addition, Zempoalteca, Barragan, Gonzalez and Guzman (2017), Gros and Silva (2005) affirmed that the relevance of the ICT regarding their communicative effects and their impact on the distance-base teaching, is a key factor in the professors' initial and continuous training.

In the view of the above, it can be stated that the professors' attitude after the CMS DOKEOS training was positive in comparison to the attitude they showed before the training. Consequently, it can be concluded that the instructional strategy denominated Workshop on Instructional Design for Online Courses using CMS DOKEOS, contributed to the change in attitude of professors toward the use of this system for EaD. 
Furthermore, the increase of the percentage of use was evident from week three to week six after the posttest administration, it is therefore concluded that professors are willing to invest more time in the effective utilization of the CMS tools, which shows a positive attitude toward the use of technological means.

Finally, it is important to mention that this research is the first referent that will allow the design and implementation of distance education programs in the host institution of this study. Hence, it can be said that the methodological development of this project can be replicated in academic institutions of the host public university and also in other higher education public institutions in Mexico.

\section{Limitations of the Study}

The main limitation of this research is that the instructional strategy was designed for the CMS DOKEOS, which means that the results from this study cannot be extrapolated to other similar systems due to possible difference of structure and technological tools, consequently the use and the instruction can be also different.

The fact that the research has been carried out at a specific time in the professors' life, can be another limitation of this study as other groups with different characteristics might show different results.

Finally, the results of this research were established by the professors' statements, who were selected intentionally. Therefore, another disadvantage is not to consider their students' opinion with the purpose of complementing a more detailed view of the attitudes that teachers have before and after being trained in the use of CMS DOKEOS.

\section{Prospective Vision of the Study}

The results obtained from this study represent part of the necessary information to design distance education programs in the host institution. Therefore, the authorities are invited to analyse the results of this research in order to make the necessary decisions in relation to the training and qualification of professors to successfully participate in distance learning methods supported by the use of the CMS DOKEOS.

As already mentioned, the results of this research work cannot be replicated in other course administration systems, because this research was focused on the CMS DOKEOS. However, the findings of this research will be useful to promote the design of instructional strategies of similar technological systems.

For future research related to the topic of attitudes, instructional design and distance education, it is recommended to propose the following lines of research: (a) studies that generate evidence and / or knowledge about the practice of facilitating learning, by means of creation, use and administration of processes information and communication and technologies, (b) evaluations and proposals that produce knowledge about the application of empirical processes of educational practice and of the different instructional theories, to the instructional design of diverse educational modalities and (c) works on the background, evolution and trends of distance education models, which serve as the basis for developing relevant proposals for distance education and design educational evaluation models of this modality. 


\section{BIODATA and CONTACT ADDRESSES of AUTHORS}

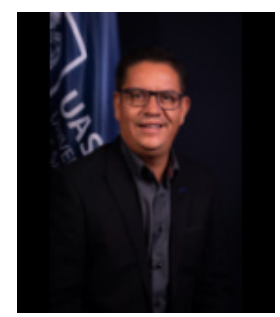

Dr. Juan Ignacio Barajas VILLARRUEL, is full time professor at the Autonomous University of San Luis Potosi (Mexico). Dr. Barajas gained his Ed.D. with a concentration in Instructional Technology and Distance Education at August, 2011. His academic interest areas are instructional design, distance education, computational thinking and educational technology. He has over than 19 journal articles published in international indexes, four international book chapters and other national and international papers submitted to international meetings.

Juan Ignacio Barajas VILLARRUEL

Address: Faculty of Accounting and Administration.

Autonomous University of San Luis Potosi, 78233, San Luis Potosi, S.L.P., Mexico.

Phone: +52 4448349916 Ext. 105.

E-mail: willie@uaslp.mx

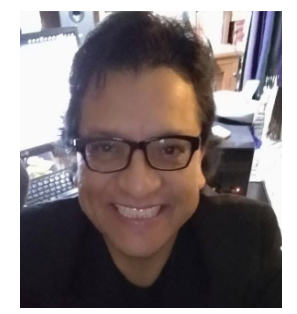

Dr. Ricardo Noyola RIVERA, is professor at the Autonomous University of San Luis Potosi (Mexico). Master Noyola gained his Degree with a concentration in educational technology at December, 2001. His academic interest areas are educational technology and distance education. Master Noyola gained his Degree with a concentration in educational technology at December, 2001. His academic interest areas are educational technology and distance education. He has 10 journal articles published in international indexes, 2 international book chapters.

Ricardo Noyola RIVERA

Address: Faculty of Accounting and Administration.

Autonomous University of San Luis Potosi, 78233, San Luis Potosi, S.L.P., Mexico.

Phone: +524448349916 Ext. 105.

E-mail: ricardo.noyola@uaslp.mx

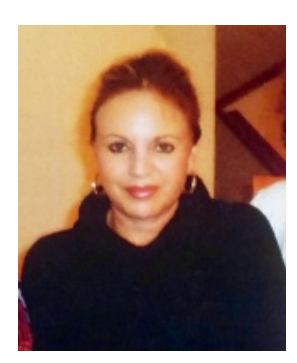

Dr. Maria Gregoria Benitez LIMA, is a full time professor at the Autonomous University of San Luis Potosi (Mexico). Dr. Benitez Lima gained her Ed.D. with a concentration in Instructional Technology and Distance Education on June 2012. Her academic interest areas are instructional design, distance education, education management and educational technology. She has over 15 journal articles published in international indexes, two international book chapters and other national and international papers submitted to international meetings. She has a long experience in designing and evaluating study plans in higher education

Maria Gregoria Benitez LIMA

Address: Faculty of Accounting and Administration.

Autonomous University of San Luis Potosi, 78233, San Luis Potosi, S.L.P., Mexico.

Phone: +52 4448349916 Ext. 105.

E-mail: gregoriabenitez@uaslp.mx 


\section{REFERENCES}

Almekhlafi, I. \& Almekhlafy, A (2010) Teachers' perceptions of the use of technology in teaching languages in United Arab Emirates' schools. [La percepcion de los profesores sobre el uso de la tecnologia en la ensenanza de idiomas en las escuelas de los Emiratos Arabes Unidos]. International Journal for Research in Education, 27, 37-56.

Amador, R. (2010). La educacion superior a distancia en Mexico. Realidades y tendencias. En P. Lupion y C. Rama (Coord.), La educacion superior a distancia en America Latina y el Caribe. Realidades $y$ tendencias (pp. 129-144). Santafe de Bogota, Virtual Educa/Pontificia Universidad Catolica de Parana/Editora Unisul.

Araiza, M. (2009). La formacion y el apoyo de profesores para el uso de las TIC en una institucion mexicana de educacion superior. Disertacion doctoral no publicada, Nova Southeastern University, Miami, FL.

Avila, P. \& Bosco, M. (2001, abril). Ambientes virtuales de aprendizaje: una nueva experiencia. Trabajo presentado en el veinteavo consejo internacional de 2001 para la educacion abierta y a distancia en Dusseldorf, Germany. Recovered from: http://investigacion.ilce.edu.mx /dice/articulos/articulo11.thm

Barajas, J., Noyola, R. \& Benitez, M. (2012). Evaluacion del Uso de un Course Managemente System (CMS). Deutschland: EAE

Barajas, J. (2015a). Diagnostico de los Servicios que se ofrecen a traves de Tecnologias de Informacion en la Facultad de Contaduria y Administracion. (Inf. Tec. No. 4). San Luis Potosi, Mexico: Universidad Autonoma de San Luis Potosi.

Barajas, J. (2015b). Informe 2015 de la estadistica de uso del CMS DOKEOS de la Facultad de Contaduria y Administracion. San Luis Potosi, Mexico: Universidad Autonoma de San Luis Potosi.

Chavez, M. (2010). Efectividad de un Curso de Capacitacion Docente Impartido en un Ambiente Virtual de Aprendizaje. Disertacion doctoral no publicada, Nova Southeastern University, Miami, FL.

De Benito, B. (2000, junio). Herramientas para la creacion, distribucion y gestion de cursos a traves de Internet. Edutec: Revista Electronica de Tecnologia Educativa, 12. Recuperado de http://edutec.rediris. es/Revelec2/ Revelec12/de-Benito.html

Edel, R., Garcia, A. \& Tiburcio, A. (2008). La Modalidad a distancia para la educacion tecnologica de postgrado: Es de interes para los egresados? Revista Electronica Iberoamericana sobre Calidad, Eficacia y Cambio en Educacion, 6(1), 154-191. Recovered from: http://www.rinace.net/arts/vol6num1/art9.pdf

Facultad de Contaduria y Administracion. (2016). Propuesta del nuevo modelo curricular para la Facultad de Contaduria y Administracion. San Luis Potosi, Mexico: UASLP.

Garrison, D. R. y Anderson, T. (2005). El e-learning en el siglo XXI. Espana: Octaedro.

George, D., \& Mallery, P. (2003). SPSS for Windows step by step: A simple guide and reference. 11.0 update (4th ed.). Boston: Allyn \& Bacon

Gonzalez, M. Laura (2017). Metodologia para el diseno instruccional en la modalidad b-learning desde la Comunicacion Educativa. Revista Razon y Palabra. Nuevos escenarios de la comunicacion educativa Vol. 21, 3_98 Julio-septiembre 2017 ISSN: 1605-4806 pp. 32-50

Graft, D. \& Albrigth, M. (2007). Administracion y evaluacion de la tecnologia instruccional y la educacion a distancia. (Monografia de investigacion No. 1). North Miami Beach Florida: Nova Southeastern University, Tecnologia Instruccional y Educacion a Distancia.

Gros, B. \& Silva, J. (2005). La formacion del profesorado como docentes en los espacios virtuales de aprendizaje. Revista Iberoamericana de Educacion, 36(1), Recovered from: http://www.rieoei.org/deloslectores/959Gros.PDF

Guardia, L. (2000). El diseno formativo: un nuevo enfoque de diseno pedagogico de los materiales didacticos en soporte digital. En Sangra A., Duart, J.M. (Comp.) Aprender en la virtualidad (pp. 171-187). Barcelona: EDIUOC/Gedisa 
Karsenti, T. \& Lira, M. L. (2011). Estan listos los futuros profesores para integrar las TIC en el contexto escolar? El caso de los profesores en Quebec, Canada. Revista Electronica de Investigacion Educativa, 13(1), 56-70. Recovered from: http://redie.uabc.mx/vol13no1/contenido-karsentilira.htm

Lignan-Camarena, L. (1999). Validacion del cuestionario sobre las actitudes de los maestros hacia la computadora. Mexico: ILCE-DICE.

Lopez, M. \& Chavez, J. (2013). La formacion de profesores universitarios en la aplicacion de las TIC. Sinectica, 41. Recuperado de: http://www.sinectica.iteso.mx/articulo/ ?id=41_la_formacion_de profesores_universitarios_en_la_aplicacion_de_las_tic

Lopez, M. (2004). Actitud de un grupo de docentes universitarios hacia el desarrollo de cursos presenciales apoyados en una Plataforma Virtual de aprendizaje despues de haber recibido capacitacion al respecto. Revistas Uned. Recovered from: http://www.virtualeduca.info/encuentros/encuentros/barcelona/2004es/ actas/5/1.5.22.doc

Lupion, P. \& Rama, C. (2010).La educacion superior a distancia en America Latina y el Caribe: Realidades y tendencias. Brasil: Unisul.

Marquez, S. (Trad.). (2005). Dokeos 1.5: Manual del desarrollador. Recovered from: http://www.dokeos. com/doc/DokeosDevManSpanish15.pdf

Nadelsticher, A. (1983). Tecnicas para la construccion de cuestionarios de actitudes y opcion multiple. Mexico: Instituto Nacional de Ciencias Penales.

Orellana, N., Almerich, G., Belloch, C. \& Diaz, I. (2004). La actitud del profesorado ante las TIC: Un aspecto clave para la integracion. Ponencia presentada en el IV Encuentro de Virtual Educa. Universidad de Barcelona (Espana). Recovered from: http://www.uv.es/ -bellochc/doc\%20UTE/VE2004_5_6.pdf

Orozco, G. (2000). Elementos para una politica de educacion mediatica. En Valderrama et al. (Eds), Comunicacion-Educacion: Coordenadas, abordajes y travesias (pp. 115-119). Santa Fe de Bogota, Colombia: Siglo del Hombre.

Rodriguez, I. (2012). Evaluacion del Programa de capacitacion profesional del docente puertorriqueno en las TIC. Disertacion doctoral no publicada, Nova Southeastern University, Miami, FL.

Robbins, S. \& Judge, T. (2009). Comportamiento Organizacional. Mexico: Pearson.

Sanchez, J. (2005). Plataformas tecnologicas para el entorno educativo. Accion Pedagogica. 14, 18-24. Recovered from: http://www.saber.ula.ve/bitstream/123456789/17239/2/articulo2.pdf

Sangra, A. (2000). Materiales en la web. Un proceso de conceptualización global. En Sangra A., Duart, J.M. (Comp.) Aprender en la virtualidad (pp. 189-202). Barcelona: EDIUOC/Gedisa

Scagnoli, N. (2005). Estrategias para motivar el aprendizaje colaborativo en cursos a distancia. Recovered from: https://www.ideals.illinois.edu/bitstream/ handle/2142 /10681/aprendizaje-colaborativo-scagnoli.pdf?sequence $=4$

Silva Q. \& Astudillo C. (2012). Insercion de TIC en la formacion inicial docente: barreras y oportunidades Revista Iberoamericana de Educacion. Revista Ibero-americana de Educaçãon. 58 (4). Recovered from: https://rieoei.org/historico/deloslectores /4557Silva.pdf

Stallman, R. (2005). Software libre para una sociedad libre. Recovered from: http://maracay.velug.org.vedocs/ free_software.pdf

Tejedor, F., Garcia-Valcarcel, A. \& Prada, S. (2009). Medida de actitudes del profesorado universitario hacia la integracion de las TIC. Revista Comunicar, 17(33), 115-124. Recovered from: http://redalyc. uaemex.mx/src/inicio/ ArtPdfRed.jsp?iCve=15812486014

Tejedor, F. \& Garcia-Valcarcel, A. (2006). Competencias de los profesores para el uso de las TIC en la ensenanza. Analisis de sus conocimientos y actitudes. Revista Espanola de Pedagogia, 233, 21-44.

UNESCO (2013). Uso de TIC en educacion en America Latina y el Caribe Analisis regional de la integracion de las TIC en la educacion y de la aptitud digital (e-readiness). Recovered from: http://unesdoc.unesco. org/images/0021/ 002193/219369s.pdf 
Vidal-Martinez, A. \& Camarena-Gomez, B. (2018). La digitalizacion de ambientes de aprendizaje: reto impostergable. Perspectiva Empresarial, 5(1), 7-16. Recovered from: http:// dx.doi.org/10.16967/ rpe.v5n1a1

Williams, P., Schrum, L., Sangra, A. \& Guardia, L. (s/f). Modelos de Diseno Instruccional. Recovered from: http://aulavirtualkamn.wikispaces.com/file/view/2.+MODELOS+DE+DISE\%C3\%91O+INSTRUCCIONAL.pdf

Zempoalteca B. Barragan J., Gonzalez J. \& Guzman T. (2017). Formacion en TIC y competencia digital en la docencia en instituciones publicas de educacion superior. Apertura (Guadalajara, Jal.), 9(1), 80-96. Recovered from: https://dx.doi.org/10.18381/Ap.v9n1.922 